\title{
Idiopathic intracranial hypertension presenting as bilateral spontaneous lateral intrasphenoidal and transethmoidal meningoceles: a case report and review of the literature
}

\author{
Aleksandar Radonjic ${ }^{3}$, Abdul Mounem Kassab ${ }^{3}$, loana D. Moldovan ${ }^{1,4}$, Shaun Kilty ${ }^{2,3,4}$ and Fahad Alkherayf $f^{1,3,4^{*}}$ (D)
}

\begin{abstract}
Background: Basal meningoceles are rare herniations of the meninges that tend to present unilaterally with cerebrospinal fluid rhinorrhea. Growing evidence suggests that intracranial hypertension contributes considerably to the formation of spontaneous basal meningoceles.

Case presentation: A 50-year-old man of Middle East ethnicity presented with a 16-week history of cerebrospinal fluid rhinorrhea, short-term memory loss, and slight decline in cognitive function. We present a case of bilateral spontaneous meningoceles with bone defects in the left lateral sphenoid sinus and right anterior cribriform plate, as well as with a remodeled sella. A neuronavigation-assisted expanded endoscopic endonasal surgery was performed to resect the meningoceles. Postoperative imaging demonstrated complete resolution of the bilateral meningoceles.

Conclusions: This case reports the first bilateral basal spontaneous meningoceles in the literature. Furthermore, based on this case's imaging results and the literature reviewed, elevated intracranial pressure may be a determining factor behind the development of spontaneous meningoceles.
\end{abstract}

Keywords: Bilateral, Spontaneous, Meningocele, Lateral intrasphenoidal, Transethmoidal, Expanded endoscopic, Endonasal, Surgery, Skull base, Case report

\section{Background}

Basal meningocele is a herniation of the meninges through a defect in the bone of the skull base. This disorder almost invariably presents with cerebrospinal fluid (CSF) rhinorrhea, and the clinical history may also include headache, vertigo, seizures, and meningitis [1]. The etiology behind spontaneous forms of this disorder has been debated; however, recent evidence points to increased intracranial pressure (ICP) as a driving cause [2]. Most spontaneous basal meningoceles present unilaterally with CSF rhinorrhea in adults. We present a case

\footnotetext{
* Correspondence: falkherayf@toh.ca

${ }^{1}$ Division of Neurosurgery, Department of Surgery, The Ottawa Hospital, Civic Campus, 1053 Carling Avenue, Room C2218, Ottawa, Ontario K1Y 4E9, Canada

${ }^{3}$ Faculty of Medicine, University of Ottawa, Ottawa, Canada

Full list of author information is available at the end of the article
}

of bilateral spontaneous left lateral intrasphenoidal and right transethmoidal meningoceles in a 50-year-old man. This is a rare finding in which two types of skull base lesions present concurrently in an adult patient with no previous history of nasal surgery or trauma.

\section{Case presentation}

A 50-year-old man of Middle East ethnicity presented with a 16-week history of CSF rhinorrhea, short-term memory loss, and slight decline in cognitive function. On physical examination, clear watery rhinorrhea, right-beating nystagmus, tongue deviation to the left side, mild facial asymmetry, multiple lipomas, bradycardia (52 beats/minute), and high blood pressure (194/118 $\mathrm{mmHg}$ ) were detected. Laboratory tests results revealed presence of beta- 2 transferrin in rhinorrhea fluid and 
hypokalemia $(3 \mathrm{mmol} / \mathrm{L})$. There were no other abnormalities in his hematology (for example, blood count) and chemistry test results (for example, liver function and CSF analysis). His past medical history was significant for: hypertension; Dercum's disease; right internal carotid dissection with pseudoaneurysm formation which was stable and conservatively treated, and followed with imaging; chronic compensated noncommunicating hydrocephalus secondary to obstruction at aqueduct of Sylvius, and a one-time seizure episode.

Computed tomography (CT) showed bony defects in his left lateral sphenoid sinus and right anterior cribriform plate (Fig. 1). CT cisternography revealed adjacent meningocele to the aforementioned defects with pooling of intrathecal contrast, confirming herniation into the left lateral sphenoid and right anterior ethmoid air cells.

Magnetic resonance imaging (MRI) demonstrated a $2.9 \times 1.8 \times 1.8 \mathrm{~cm}$ right anterior meningocele traversing the anterior cribriform plate inferiorly into anterior ethmoid air cells and nasopharynx with extension into the right maxillary sinus (Fig. 2a). Another contrast extension from the left middle cranial fossa along its most anterior aspect into the most lateral aspect of the sphenoid sinus was identified suggesting a second meningocele measuring $1 \times 1 \times 0.9 \mathrm{~cm}$ (Fig. 2b). Both lesions were enhanced with gadolinium but no brain parenchyma could be identified within the sacs. Other findings on MRI included a significantly flattened pituitary gland within a remodeled sella and a slightly dilated ventricular system.

$\mathrm{He}$ underwent neuronavigation-assisted expanded endoscopic endonasal surgery with resection of the anterior skull base meningoceles. The first lesion was right ethmoidal and the second lesion was left sphenoidal. Repair of the dura was carried out with two layers of dural matrix. Insertion of a lumbar drain was done to drain CSF and for injection of fluorescein to help confirm dural seal. Opening pressure upon insertion of the lumbar drain at the time of surgery was $20 \mathrm{mmHg}$. Septal and anterior ethmoidal flaps were used to support the repair of the sphenoid and anterior ethmoidal lesions, respectively. He recovered uneventfully and postoperative imaging showed complete resolution of the meningoceles bilaterally (Fig. 3).

Four weeks after the surgery, he presented to our clinic with CSF leak and headache. MRI revealed evidence of CSF leak noted within the left sphenoid sinus. He underwent an endoscopic repair of the CSF leak and insertion of a ventriculoperitoneal shunt. Postoperation, he recovered well and presented no symptoms. He had 3-year follow up with no recurrence of the meningoceles.

\section{Discussion}

We presented a rare case of a 50-year-old man with bilateral spontaneous lateral intrasphenoidal and transethmoidal meningoceles with nasal herniation and CSF rhinorrhea, associated with a significantly flattened pituitary gland within a remodeled sella.

Nasal meningoceles are herniations of the meninges into the nasal cavity [3]. Similar complications include encephaloceles (only the brain tissue is herniated) and meningoencephaloceles (both brain and meningeal tissues herniate). The location of the bone defect in the skull defines whether a meningocele is frontal, occipital, parietal, or basal [4].

The two types of basal meningoceles noted in this case report are transethmoidal and intrasphenoidal. Transsphenoidal lesions have been further classified as intrasphenoidal if the protrusion passes into but not through the sphenoid sinus [5]. There is some debate in the literature on whether intrasphenoidal defects are more common in the midline or the lateral recess [6]. Midline, perisellar sphenoid lesions were found to occur almost exclusively in obese women [6]. Pneumatization of the
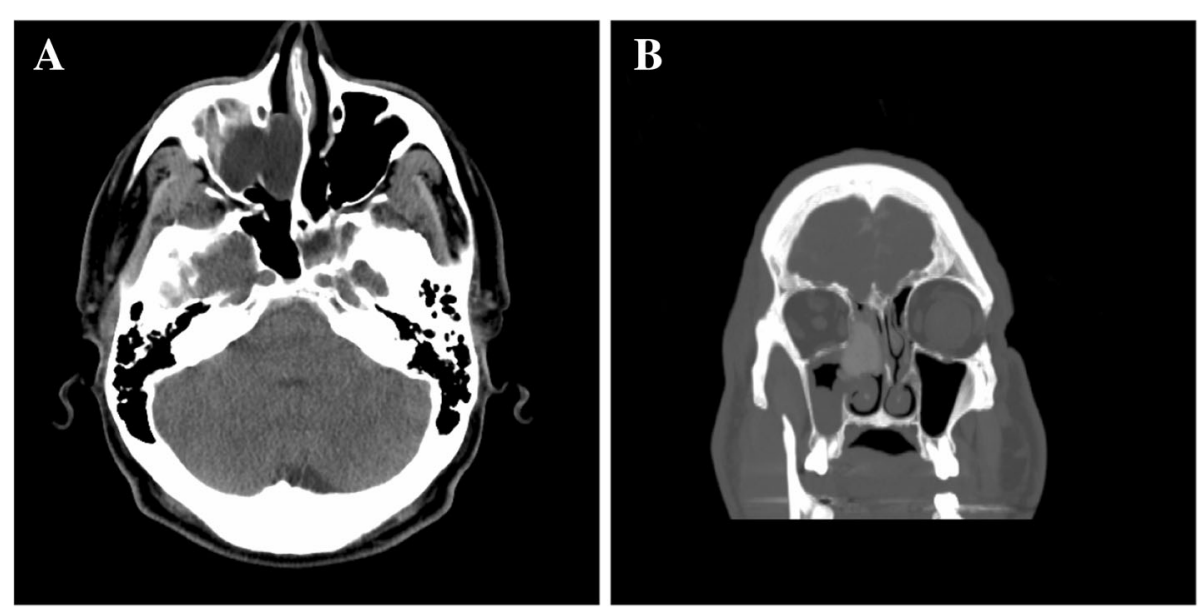

Fig. 1 Computed tomography without contrast, preoperative images. a Axial and $\mathbf{b}$ coronal computed tomography images showed bony defects in the left lateral sphenoid sinus and right anterior cribriform plate 


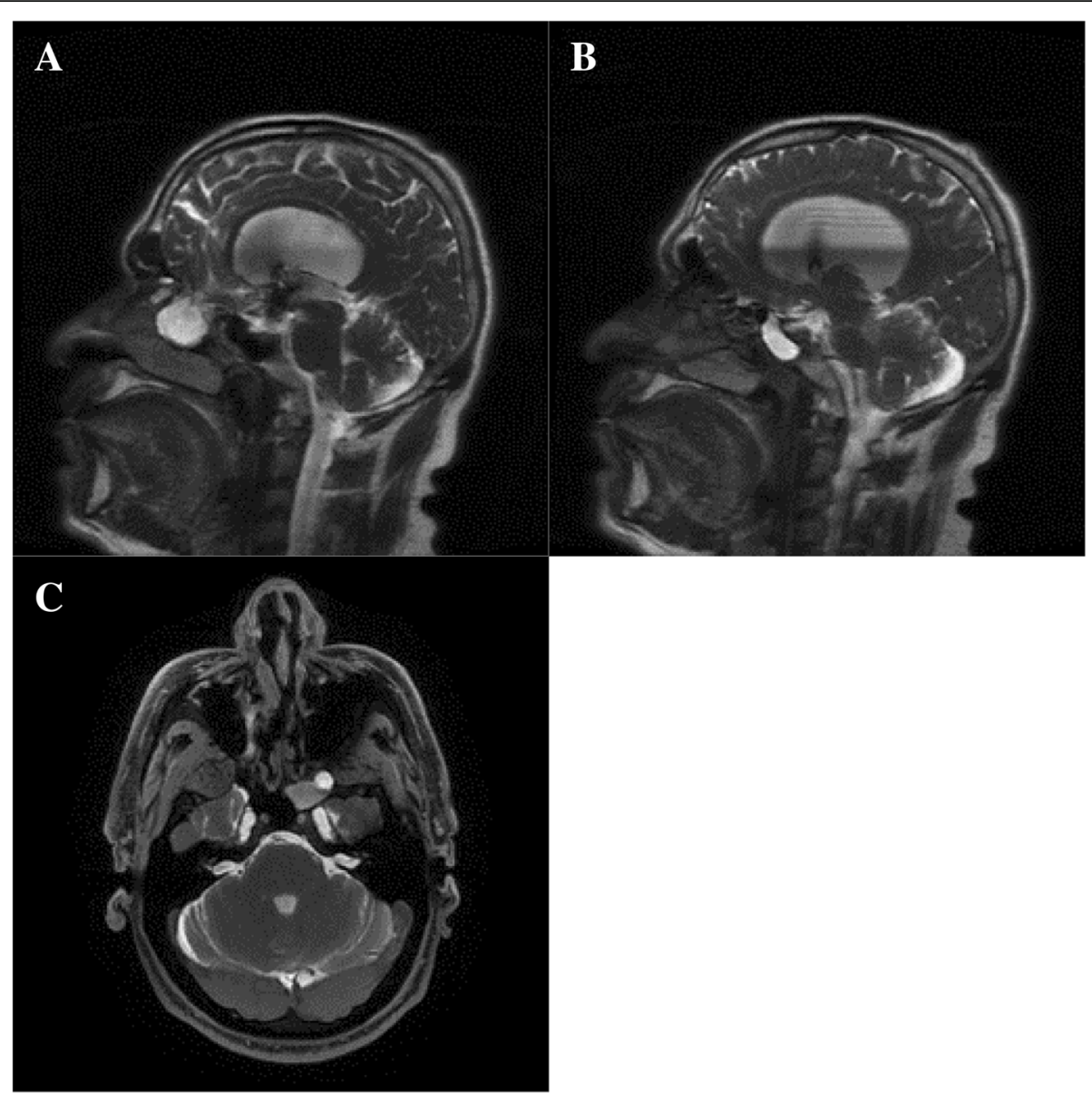

Fig. 2 Magnetic resonance imaging cisternography, preoperative images. a and b Sagittal magnetic resonance imaging cisternography images showing right anterior ethmoidal (a) and left sphenoidal (b) meningoceles. c Axial magnetic resonance imaging cisternography image showing left sphenoidal meningocele
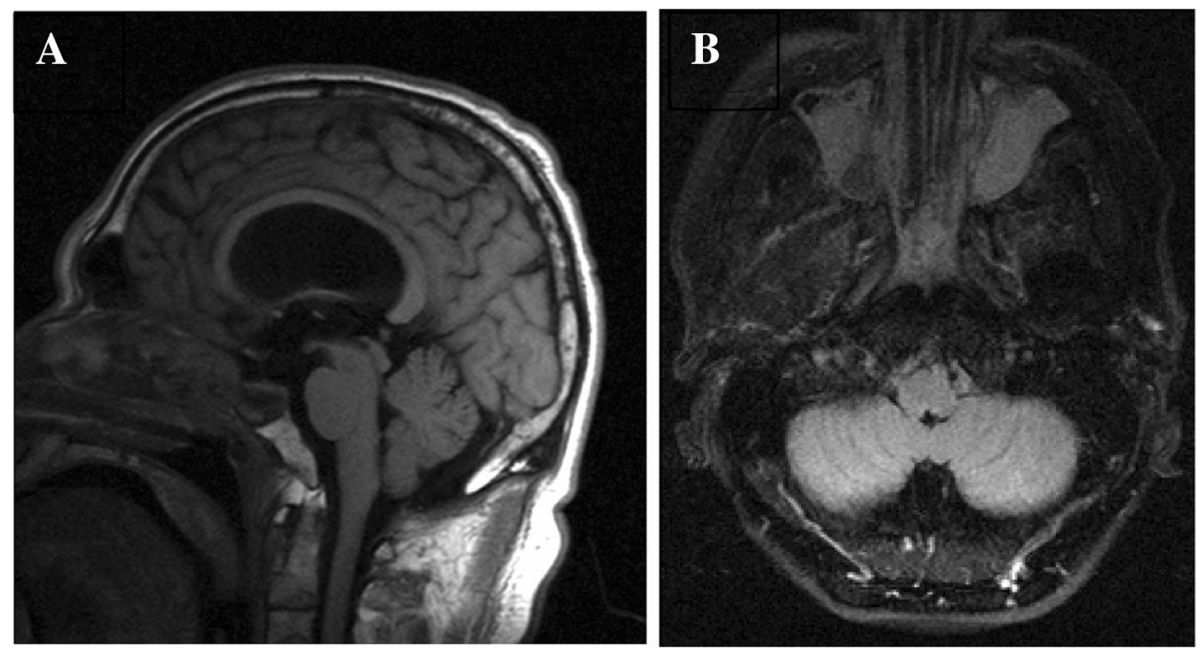

Fig. 3 Magnetic resonance imaging without contrast, postoperative images. a Sagittal and $\mathbf{b}$ axial magnetic resonance imaging postoperative images showed no evidence of residual meningoceles 
Table 1 Reported cases of spontaneous basal intrasphenoidal, transethmoidal, and bilateral herniations including meningoceles, encephaloceles, and meningoencephaloceles

\begin{tabular}{|c|c|c|c|c|c|}
\hline Authors & Age, sex & Location & Type of herniation & $\begin{array}{l}\text { Cerebrospinal fluid } \\
\text { rhinorrhea?* }\end{array}$ & Bony defect \\
\hline & Transethmoidal & & & & \\
\hline $\begin{array}{l}\text { Sharifi et al. [10] } \\
2014\end{array}$ & $35 \mathrm{~F}$ & Right & Meningoencephalocele & Yes & Ethmoid sinus \\
\hline $\begin{array}{l}\text { Hasegawa et al. } \\
\text { [11] } 2005\end{array}$ & $52 \mathrm{M}$ & Right & Meningoencephalocele & Yes & Cribriform \\
\hline $\begin{array}{l}\text { Singh et al. [29] } \\
2013\end{array}$ & $42 \mathrm{M}$ & Left & Meningocele & No & Cribriform \\
\hline $\begin{array}{l}\text { Schwartz and } \\
\text { Shaw [12] } 2002\end{array}$ & $62 \mathrm{M}$ & Left & Meningoencephalocele & Yes & Cribriform \\
\hline $\begin{array}{l}\text { Thijssen et al. [13] } \\
1976\end{array}$ & $24 \mathrm{~F}$ & Left & Encephalocele & Yes & Cribriform \\
\hline \multirow[t]{2}{*}{$\begin{array}{l}\text { Ziade et al. [14] } \\
2016\end{array}$} & $\begin{array}{l}47.5 \text { (median age) } 8 \\
\text { Females } 2 \text { Males }\end{array}$ & \multirow[t]{2}{*}{$\begin{array}{l}3 \text { left, } 7 \\
\text { right }\end{array}$} & \multirow[t]{2}{*}{$\begin{array}{l}7 \text { meningoceles, } 3 \\
\text { meningoencephaloceles }\end{array}$} & \multirow[t]{2}{*}{ Yes, all } & \multirow[t]{2}{*}{ Cribriform, all } \\
\hline & Intrasphenoidal & & & & \\
\hline $\begin{array}{l}\text { Stefanelli et al. } \\
\text { [15] } 2014\end{array}$ & $41 \mathrm{M}$ & Right & Meningoencephalocele & No & Greater wing of sphenoid \\
\hline $\begin{array}{l}\text { Kwon and Kim } \\
\text { [16] } 2010\end{array}$ & $45 \mathrm{~F}$ & Right & Meningoencephalocele & Yes & Pneumatized SS \\
\hline $\begin{array}{l}\text { Fraioli et al. [17] } \\
2003\end{array}$ & $59 \mathrm{M}$ & Right & Encephalocele & Yes & Lateral SS \\
\hline $\begin{array}{l}\text { Alfieri et al. [18] } \\
2002\end{array}$ & $63 \mathrm{~F}$ & Right & Encephalocele & Yes & Lateral SS \\
\hline $\begin{array}{l}\text { Daniilidis et al. } \\
\text { [19] } 1999\end{array}$ & $46 \mathrm{~F}$ & Right & Encephalocele & Yes & Lateral SS \\
\hline $\begin{array}{l}\text { Deasy et al. [20] } \\
1999\end{array}$ & $40 \mathrm{~F}, 59 \mathrm{M}$ & Right & Encephalocele & Yes, both & Lateral SS \\
\hline $\begin{array}{l}\text { Clyde and } \\
\text { Stechison [21] } \\
1995\end{array}$ & $54 \mathrm{~F}$ & Right & Meningoencephalocele & Yes & Lateral SS \\
\hline $\begin{array}{l}\text { Peltonen et al. } \\
\text { [22] } 2008\end{array}$ & $60 M$ & Left & Encephalocele & Yes & Roof of SS \\
\hline $\begin{array}{l}\text { Herman et al. [23] } \\
2003\end{array}$ & $45 \mathrm{~F}$ & Left & Meningoencephalocele & Yes & Ptosis, floor of third ventricle \\
\hline $\begin{array}{l}\text { Willner et al. [24] } \\
1994\end{array}$ & $67 \mathrm{~F}$ & Left & Encephalocele & Yes & N/A \\
\hline $\begin{array}{l}\text { Albernaz et al. [25] } \\
1991\end{array}$ & $47 \mathrm{~F}$ & Left & Encephalocele & No & Middle cranial fossa \\
\hline $\begin{array}{l}\text { Buchfelder et al. } \\
\text { [26] } 1987\end{array}$ & $44 \mathrm{~F}$ & Left & Encephalocele & Yes & Lateral SS \\
\hline $\begin{array}{l}\text { Sanjari et al. [8] } \\
2013\end{array}$ & $45 \mathrm{~F}$ & Left & Meningocele & Yes & Lateral SS \\
\hline $\begin{array}{l}\text { Ogul et al. [27] } \\
2014\end{array}$ & $42 \mathrm{~F}$ & N/A & Encephalocele & No & Hypomineralization of sphenoid bone \\
\hline $\begin{array}{l}\text { Abiko et al. [5] } \\
1988\end{array}$ & $46 \mathrm{~F}$ & N/A & Encephalocele & No & Erosion of planum sphenoidale \\
\hline \multirow[t]{2}{*}{ Lai et al. [6] 2002} & $\begin{array}{l}52.3 \text { (mean age) } 7 \\
\text { females, } 5 \text { males }\end{array}$ & $\begin{array}{l}7 \text { left, } 5 \\
\text { right }\end{array}$ & Encephaloceles (all) & $3 / 12$ & 8 lateral SS, 4 midline perisellar \\
\hline & Bilateral & & & & \\
\hline $\begin{array}{l}\text { Firat and Firat [28] } \\
2004\end{array}$ & $53 \mathrm{M}$ & Both & Meningoencephaloceles & Yes & $\begin{array}{l}\text { Cribriform, lateral SS, anterior + posterior } \\
\text { frontal sinus }\end{array}$ \\
\hline $\begin{array}{l}\text { Aggarwal et al. } \\
\text { [2]2017 }\end{array}$ & $44 \mathrm{M}$ & Both & Meningoencephaloceles & Yes & Bilateral DAVF \\
\hline
\end{tabular}


Table 1 Reported cases of spontaneous basal intrasphenoidal, transethmoidal, and bilateral herniations including meningoceles, encephaloceles, and meningoencephaloceles (Continued)

\begin{tabular}{|c|c|c|c|c|c|}
\hline Authors & Age, sex & Location & Type of herniation & $\begin{array}{l}\text { Cerebrospinal fluid } \\
\text { rhinorrhea?* }\end{array}$ & Bony defect \\
\hline $\begin{array}{l}\text { Schlosser and } \\
\text { Bolger [9] } 2002\end{array}$ & $\begin{array}{l}49.2 \text { (mean age) } 4 \\
\text { females, } 1 \text { male }\end{array}$ & Both & $\begin{array}{l}\text { Meningoencephaloceles } \\
\text { (all 5) }\end{array}$ & $4 / 5$ yes & $\begin{array}{l}\text { Bilateral lateral SS } \times 3 \text {, posterior ethmoid/ } \\
\text { frontal, frontal/central sphenoid }\end{array}$ \\
\hline
\end{tabular}

DAVF dural arteriovenous fistula, $F$ female, $M$ male, $N / A$ not available, $S S$ sphenoid sinus, ${ }^{*}$ cerebrospinal fluid rhinorrhea at presentation

lateral sphenoid sinus, followed by pulsatile forces within the CSF, may lead to the formation of gaps in the bone found in lateral sphenoid lesions [7]. Our review of the literature found that 17 of 28 reported spontaneous intrasphenoidal lesions involved the lateral recess of the sphenoid sinus. Of those 17 lateral defects, 10 cases involved the right side (Table 1).

Spontaneous intrasphenoidal meningoceles, herniations limited to brain meninges, are rare; only one has been reported in the literature [8]. Most cases involve brain tissue and are generally unilateral $[2,5,6,9-28]$. On the other hand, spontaneous transethmoidal lesions typically involve meningeal tissue, in the form of a meningocele or a meningoencephalocele [10-14, 29] (Table 1).

Our case reports a finding of bilateral meningoceles in an adult male involving both transethmoidal and lateral recess intrasphenoidal lesions. The bilateral nature of this lesion is a rare finding. As far as we know, no cases of bilateral, basal spontaneous meningoceles have been reported in the literature. However, seven cases of spontaneous bilateral meningoencephaloceles have been reported [2, 9, 28]. Of these, five patients had bilateral lateral recess intrasphenoidal meningoencephaloceles $[2$, 9,28 ] (Table 1). No cases involved both transethmoidal and intrasphenoidal lesions. Thus, as far as we know, our case reports the first finding of bilateral basal spontaneous meningoceles in the literature. Furthermore, it depicts the first case of bilateral intrasphenoidal and transethmoidal defects with nasal herniation of any kind in the literature.

The etiology of basal meningoceles has historically been classed into congenital, iatrogenic, traumatic, and spontaneous causes [9]. Spontaneous cases almost invariably present as CSF rhinorrhea in adult patients [2, $6,8-14,16-24,26,28,29]$. The mean age of the 15 spontaneous transethmoidal reported cases was 46 at presentation $[10-14,29]$. Only one of these patient's histories did not include CSF rhinorrhea [29]. Similarly, the mean age of the 28 spontaneous intrasphenoidal reported cases was 51 with 15 showing signs of CSF rhinorrhea [5, 6, 8, 15-27] (Table 1). Traditionally, the spontaneous category was synonymous with idiopathic as it was reserved for CSF leaks that did not have a discernable cause [30]. However, recent literature strongly suggests that many spontaneous causes are the result of increased ICP [2]. One common sign of elevated ICP is empty sella syndrome. This is manifested radiologically as an empty sella due to compression of the pituitary gland as CSF replaces normal pituitary space [31]. Schlosser and Bolger found that all four of their patients with bilateral meningoencephaloceles had positive empty sella syndrome on radiography [9]. On MRI, we found a significantly flattened pituitary gland within a remodeled sella, indicative of empty sella syndrome as well. This finding, in the absence of congenital, tumor, or traumatic etiology, may strengthen the argument that elevated ICP is implicated in the formation of a spontaneous meningocele.

\section{Conclusion}

Our case reports the first spontaneous bilateral left lateral intrasphenoidal and right transethmoidal meningoceles in an adult male. This case highlights evidence that elevated ICP may be a determining factor behind spontaneous meningoceles.

\section{Acknowledgements \\ Not applicable.}

Funding

There was no funding for this case report.

\section{Authors' contributions}

All authors made substantial contributions to the conception of this case report. AMK and AR made substantial contributions to literature search and acquisition of data. All authors made substantial contributions to interpretation of data. All authors have been involved in drafting the manuscript and revising it critically for important intellectual content. All authors have given final approval of the version to be published. Each author has participated sufficiently in the work and takes public

responsibility for appropriate portions of the content, and all authors agreed to be accountable for all aspects of the work in ensuring that questions related to the accuracy or integrity of any part of the work are appropriately investigated and resolved.

\section{Ethics approval and consent to participate \\ Not applicable.}

\section{Consent for publication}

Written informed consent was obtained from the patient for publication of this case report and any accompanying images. A copy of the written consent is available for review by the Editor-in-Chief of this journal.

Competing interests

The authors declare that they have no competing interests.

\section{Publisher's Note}

Springer Nature remains neutral with regard to jurisdictional claims in published maps and institutional affiliations. 


\section{Author details}

'Division of Neurosurgery, Department of Surgery, The Ottawa Hospital, Civic Campus, 1053 Carling Avenue, Room C2218, Ottawa, Ontario K1Y 4E9, Canada. ${ }^{2}$ Department of Otolaryngology - Head \& Neck Surgery, The Ottawa Hospital, Ottawa, Canada. ${ }^{3}$ Faculty of Medicine, University of Ottawa, Ottawa, Canada. ${ }^{4}$ The Ottawa Hospital Research Institute, Ottawa, Canada.

Received: 29 June 2018 Accepted: 19 December 2018

Published online: 05 March 2019

\section{References}

1. Wise SK, Schlosser RJ. Evaluation of spontaneous nasal cerebrospinal fluid leaks. Curr Opin Otolaryngol Head Neck Surg. 2007;15(1):28-34.

2. Aggarwal $V$, Nair $P$, Shivhare $P$, Jayadevan ER, Felix V, Abraham M, Nair SA. Case of Evolving Bilateral Sphenoidal Meningoencephaloceles: Case Report and Review of the Literature. World Neurosurg. 2017;100:708-e11.

3. Bhat M. A case of intranasal meningocele. McGill J Med. 2006;9(1):31.

4. Suwanwela C, Suwanwela N. A morphological classification of sincipital encephalomeningoceles. J Neurosurg. 1972;36(2):201-11.

5. Abiko S, Aoki H, Fudaba H. Intrasphenoidal encephalocele: report of a case. Neurosurgery. 1988;22(5):933-6.

6. Lai SY, Kennedy DW, Bolger WE. Sphenoid encephaloceles: disease management and identification of lesions within the lateral recess of the sphenoid sinus. Laryngoscope. 2002;112(10):1800-5.

7. Hamid O, El Fiky L, Hassan O, Kotb A, El Fiky S. Anatomic variations of the sphenoid sinus and their impact on trans-sphenoid pituitary surgery. Skull Base. 2008;18(1):9.

8. Sanjari R, Mortazavi SA, Amiri RS, Ardestani SS, Amirjamshidi A. Intrasphenoidal meningo-encephalocele: report of two rare cases and review of literature. Surg Neurol Int. 2013;4 https://doi.org/10.4103/21527806.106260.

9. Schlosser RJ, Bolger WE. Management of multiple spontaneous nasal meningoencephaloceles. Laryngoscope. 2002;112(6):980-5.

10. Sharifi G, Alavi E, Jalessi M, Haddadian K, Faramarzi F. Transethmoidal encephalocele after reduction of high intracranial pressure in aqueductal stenosis. Turk Neurosurg. 2014;24(1):75-7.

11. Hasegawa T, Sugeno N, Shiga Y, Takeda A, Karibe H, Tominaga T, Itoyama Y. Transethmoidal intranasal meningoencephalocele in an adult with recurrent meningitis. J Clin Neurosci. 2005;12(6):702-4.

12. Schwartz MD, Shaw GJ. Bacterial meningitis secondary to a transethmoidal encephalocele presenting to the emergency department. J Emerg Med. 2002;23(2):171-4.

13. Thijssen HO, Walder HA, Wentges RT, Slooff JL, Meyer E. Acquired basal encephalocele. Neuroradiology. 1976;11(4):209-13.

14. Ziade G, Hamdan AL, Homsi MT, Kazan I, Hadi U. Spontaneous transethmoidal meningoceles in adults: case series with emphasis on surgical management. Sci World J. 2016;2016. https://doi.org/10.1155/2016/ 3238297.

15. Stefanelli S, Barnaure I, Momjian S, Seeck M, Constantinescu I, Lovblad KO, Vargas MI. Incidental intrasphenoidal encephalocele(ise). J Neuroradiol. 2014; 41(5):358-60.

16. Kwon JE, Kim E. Middle Fossa Approach to a Temporosphenoidal Encephalocele. Neurol Med Chir. 2010;50(5):434-8.

17. Fraioli B, Conti C, Lunardi P, Liccardo G, Fraioli MF, Pastore FS. Intrasphenoidal encephalocele associated with cerebrospinal fluid fistula and subdural hematomas: technical case report. Neurosurgery. 2003;52(6): 1487-90.

18. Alfieri A, Schettino R, Taborelli A, Pontiggia M, Reganati P, Ballarini V, Monolo L. Endoscopic endonasal treatment of a spontaneous temporosphenoidal encephalocele with a detachable silicone balloon: Case report. J Neurosurg. 2002;97(5):1212-6.

19. Daniilidis J, Vlachtsis K, Ferekidis E, Dimitriadis A. Intrasphenoidal encephalocele and spontaneous CSF rhinorrhoea. Rhinology. 1999;37(4):186-9.

20. Deasy NP, Jarosz JM, Al Sarraj S, Cox TC. Intrasphenoid cephalocele: MRI in two cases. Neuroradiology. 1999;41(7):497-500.

21. Clyde BL, Stechison MT. Repair of temporosphenoidal encephalocele with a vascularized split calvarial cranioplasty: technical case report. Neurosurgery. 1995;36(1):202-14.

22. Peltonen E, Sedlmaier B, Brock M, Kombos T. Persistent cerebrospinal fluid rhinorrhea by intrasphenoidal encephalocele. Central European Neurosurgery-Zentralbl Neurochir. 2008 Nov;69(04):187-90.
23. Herman P, Guichard JP, Sauvaget E, Huy PT. Intrasphenoidal transsellar encephalocele repaired by endoscopic approach. Ann Otol Rhinol Laryngol. 2003;112(10):890-3.

24. Willner A, Kantrowitz AB, Cohen AF. Intrasphenoidal encephalocele: diagnosis and management. Otolaryngology-Head and Neck. Surgery. 1994;111(6):834-7.

25. Albernaz MS, Horton WD, Adkins WY, Garen PD. Intrasphenoidal encephalocele. Otolaryngol_-Head Neck Surg. 1991;104(2):279-81.

26. Buchfelder M, Fahlbusch R, Huk WJ, Thierauf P. Intrasphenoidal encephaloceles - a clinical entity. Acta Neurochir. 1987;89(1-2):10-5.

27. Ogul H, Yuce I, Kantarci M. Unusual Cause of the Headache and Hypophyseal Insufficient: Intrasphenoidal Encephalocele. Headache. 2014; 54(9):1531-3.

28. Firat AK, Firat Y. Spontaneous bilateral intrasphenoidal lateral encephaloceles: CT and MRI findings. ENT-Ear Nose Throat J. 2004:83(12): 831-3.

29. Singh DK, Singh N, Singh R. Transethmoidal meningocele: an unusual complication of intracranial neoplasm. BMJ Case Rep. 2013;2013. https://doi. org/10.1136/bcr-2013-009200.

30. Papanikolaou V, Bibas A, Ferekidis E, Anagnostopoulou S, Xenellis J. Idiopathic temporal bone encephalocele. Skull Base. 2007;17(5):311.

31. Wang EW, Vandergrift WA, Schlosser RJ. Spontaneous CSF leaks. Otolaryngol Clin N Am. 2011;44(4):845-56.
Ready to submit your research? Choose BMC and benefit from:

- fast, convenient online submission

- thorough peer review by experienced researchers in your field

- rapid publication on acceptance

- support for research data, including large and complex data types

- gold Open Access which fosters wider collaboration and increased citations

- maximum visibility for your research: over $100 \mathrm{M}$ website views per year

At BMC, research is always in progress.

Learn more biomedcentral.com/submissions 